\title{
Aerial Parts of Peucedanum chenur Have Anti-Cancer Properties through the Induction of Apoptosis and Inhibition of Invasion in Human Colorectal Cancer Cells
}

\author{
Saeed Yadegari ${ }^{1}$, Massuod Saidijam ${ }^{1}$, Mohammadreza \\ Moradi $^{1}$, Dara Dastan ${ }^{2,3}$ and Ali Mahdavinezhad ${ }^{1 *}$

\begin{abstract}
${ }^{1}$ Research Center for Molecular Medicine and Genetics, Hamadan University of Medical Sciences, Hamadan, Iran; ${ }^{2}$ Medicinal Plants and Natural Products Research Center, Hamadan University of Medical Sciences, Hamadan, Iran; ${ }^{3}$ Department of Pharmacognosy and Pharmaceutical Biotechnology, School of Pharmacy, Hamadan University of Medical Sciences, Hamadan, Iran
\end{abstract}

Received 13 January 2019; accepted 1 September 2019; published online 4 March 2020

\begin{abstract}
Background: The Peucedanum species have many pharmacological effects due to the presence of coumarins, flavonoids, phenolic compounds, and essential fatty acids in these species. In this study, for the first time, the anticancer activity of Peucedanum chenur methanolic extract via the induction of apoptosis and inhibition of invasion in HCT-116 human colon cancer cells was investigated. Methods: $P$. chenur methanolic extract effect on HCT-116 cells viability and antioxidant activity were evaluated using MTT assay, DPPH, and iron chelating tests, respectively. Changes in mRNA expression level in a panel of relevant genes were assessed by the quantitative real-time PCR. Also, apoptosis was assessed by cell cycle analysis and Annexin V/PI method, and the effect on cell migration was tested using scratch test. Results: $P$. chenur methanolic extract increased significantly the expression of $B A X$ while decreased the expression of $B C L-2, A K T 1, F A K$, RhoA, and MMP genes compared to the control group. $B A X / B C L-2$ ratio and apoptosis elevated, whereas cell migration reduced significantly. Besides, our extract showed an appropriate antioxidant activity. Conclusion: $P$. chenur may be introduced as a new chemopreventive agent in medicine due to its notable power in terms of induction of apoptosis and inhibition of invasion. DOI: 10.29252/ibj.24.5.309
\end{abstract}

Keywords: Antioxidant, Apoptosis, Colorectal neoplasm, Medicinal plant, Neoplasm invasiveness

Corresponding Author: Ali Mahdavinezhad

Research center for Molecular Medicine, Department of Genetics and Molecular Medicine, Hamadan University of Medical Sciences, Hamadan 6517838736, Iran; Tel.: (+98-918) 8521900; Fax: (+98-81) 38380208; E-mail: alimahdavin@gmail.com

\section{INTRODUCTION}

$\longrightarrow$ olorectal cancer is the third common cancer in the world ${ }^{[1]}$. Current methods for treating CRC include surgery, chemotherapy, and radiation therapy ${ }^{[2]}$. Resistance to apoptosis and tissue invasion are key features of cancer cells ${ }^{[3]}$. On the other hand, cell migration, as a complex process, critically contributes to cancer invasion and metastasis ${ }^{[4]}$. Cancer progression occurs due to changes in the cell microenvironment and activation of extracellular proteases, thereby causing tumor cell motility and moving to distant tissues through the bloodstream, which results in metastasis ${ }^{[5]}$.

Nowadays, herbal medicinal products have gained more attention than synthetic drugs because they are cheaper, safer, and more accessible and have fewer drug interactions ${ }^{[2,6]}$, and unlike synthetic compounds, they influence several signaling pathways in cancer cells ${ }^{[7]}$. Studies have shown that some natural 
compounds can induce apoptosis in cancer cells, which leads to homeostasis in tissues ${ }^{[8,9]}$. Therefore, finding a suitable natural compound to induce apoptosis in cancerous cells and inhibit invasion activity of them is considered as a scientific achievement.

The genus Peusedanum has more than 120 species and grows in Europe, Asia, and Africa. The pharmacological properties of Peucedanum species are attributed to coumarin, flavonoids, phenolic compounds, and essential fatty acids ${ }^{[10]}$. Peucedanum chenur is an endemic species of Kurdistan Province in the west of Iran, and to the best of our knowledge, the anticancer properties of this species has not yet been assessed. Therefore, in this study, the anticancer effects of $P$. chenur methanolic extract on HCT-116 human colon carcinoma cells were investigated. Further to general assays like MTT assay and scratch test, we tried to determine the expression levels of apoptosis and invasion related genes such as $B A X, B C L-2, A K T 1$, $F A K$, RhoA, and $M M P-13$. Also, antioxidant activity of the plant extract was evaluated by two relevant assays,DPPH and iron ions chelating. This survey is the first study aimed at investigating the mechanism of action for antitoxicity effect of the $P$. chenur.

\section{MATERIALS AND METHODS}

\section{Preparation of $\boldsymbol{P}$. chenur extract}

$P$. chenur was collected from Kurdistan Province, Iran. A voucher specimen (no. 2951) was registered in the herbarium of the Research Institute of Forests and Rangelands, Sanandaj, Iran. Aerial parts of $P$. chenur (180 g) were cut into small pieces and an Erlenmeyer flask to extract methanolic extract according to maceration method through shaking. After 72 hours, methanolic extract was passed through a Whatman filter paper and concentrated in vacuum at $50{ }^{\circ} \mathrm{C}$ using a rotary evaporator. The extract was kept in a sterile vial in the dark and a cool place until use.

\section{Cell culture}

HCT-116 and Vero cells were prepared from the National Cell Bank of Iran, Pasteur Institute of Iran, Tehran. The cells were cultured in a T25 flask using DMEM medium (Thermo Fisher Scientific, USA) containing 10\% FBS (Thermo Fisher Scientific), 100 $\mathrm{U} / \mathrm{ml}$ of penicillin, and $100 \mu / \mathrm{ml}$ of streptomycin (Kiazist Life Sciences, Iran). Incubation conditions included a temperature of $37{ }^{\circ} \mathrm{C}, 5 \%$ carbon dioxide, and $95 \%$ relative humidity.

\section{Cell viability assay}

Viability of extract-treated HCT-116 and Vero cells was investigated using the MTT assay in a dose -and time-dependent manner in the same way. Optimum cell density was determined according to the method used by Moradi et al. ${ }^{[1]}$, and $6 \times 10^{3}$ cells were seeded in each well of a 96-well plate. The cells were kept at $37{ }^{\circ} \mathrm{C}$ for 24 hours, then different concentrations of methanolic extract of $P$. chenur $(20,60,100,140,180$, $220,260,300,340$, and $380 \mu \mathrm{g} / \mathrm{ml}$ ) were added to each well. The first and second rows were selected as the negative and positive controls (by adding $21 \mu \mathrm{l} /$ well of DMSO in order to see apoptotic form of HCT-116 cells), respectively. After incubation times (24, 48, and 72 hours), $10 \mu \mathrm{l}(5 \mathrm{mg} / \mathrm{ml})$ of MTT solution (Sigma Aldrich, USA) was added to each well and was incubated again at $37{ }^{\circ} \mathrm{C}$ for 4 hours. Subsequently, in a low light environment, entire contents of the wells were removed, and $100 \mu \mathrm{l}$ of DMSO was added to each well to dissolve formazan crystals. Finally, OD was measured by an ELISA reader at $570 \mathrm{~nm}$, and experiments were repeated three times. To find optimum $\mathrm{IC}_{50}$ within 24, 48, and 72 hours, Pearson correlation coefficient was calculated to show correlation between the viability of cells and concentrations. $\mathrm{IC}_{50}$ value for 48-hour incubation time (182.1 $\mu \mathrm{g} / \mathrm{ml}$ ) was considered as optimum concentration for the next experiments. To determine $\mathrm{IC}_{50}$ value for Vero cells, the cells were treated with final concentrations of $0,360,420,480,540$, and 600 $\mu \mathrm{g} / \mathrm{ml}$ of extract in each well for 48 -hour incubation time.

\section{Gene expression analysis}

\section{RNA extraction and cDNA synthesis}

As mentioned earlier in cell viability assay Section, $\mathrm{IC}_{50}$ value $(182.1 \mu \mathrm{g} / \mathrm{ml})$ for 48 -hour incubation time was considered as optimum concentration for the next experiments. Therefore, incubation time of methanolic extract of $P$. chenur for real-time PCR test was 48 hour. Total RNA of the treated cells was extracted by RNX-plus (CinnaGen, Iran) according to the instruction of the kit. Quality and concentration of the extracted RNA were assessed by $2 \%$ agarose gel electrophoresis and Nanodrop (Biotech, USA). cDNA synthesis was performed using the Primecript RT reagent kit (Takara, Japan) as per the manufacturer's instruction.

\section{Real-time PCR}

Gene expression analysis was performed using quantitative real-time PCR technique by Roche LightCycler® 96 system according to Moradi et al.'s method $^{[12]}$. Specificity of primer pairs was investigated by NCBI primer blast, and quantitative real-time PCR was performed in duplicate on mixture containing $1 \mu \mathrm{l}$ of $8 \mathrm{pmol} / \mathrm{mL}$ specific primer pairs (Table 1), $7 \mu \mathrm{l}$ of water, $10 \mu \mathrm{l}$ of SYBR Premix Ex 
Table 1. Characteristics and sequence of primers

\begin{tabular}{|c|c|c|}
\hline Gene name & Accession number & Primer sequence \\
\hline GAPDH & NM-002046.6 & $\begin{array}{l}\text { Forward: 5'-AAGGCTGTGGGCAAGGTCATC-3' } \\
\text { Reverse: 5'-GCGTCAAAGGTGGAGGAGTGG-3' }\end{array}$ \\
\hline$B A X$ & NM-138761.3 & $\begin{array}{l}\text { Forward: 5'-CGCCGTGGACACAGACTC-3' } \\
\text { Reverse: 5'-GCCTTGAGCACCAGTTTG-3' }\end{array}$ \\
\hline$B C L-2$ & NM-000657.2 & $\begin{array}{l}\text { Forward: 5-TGGAGAGTGCTGAAGATTGA-3 } \\
\text { Reverse: 5-GTCTACTTCCTCTGTGATGTTGTAT-3 }\end{array}$ \\
\hline$A K T 1$ & NM-005163.2 & $\begin{array}{l}\text { Forward: 5'-GTGGCTATTGTGAAGAGA-3' } \\
\text { Reverse: 5'-GGATGATGAAGGTGTTGG-3' }\end{array}$ \\
\hline$F A K$ & NM_001352696.1 & $\begin{array}{l}\text { Forward: 5'-CCTCGCAGTCATTTATCATCAG-3' } \\
\text { Reverse: 5'-CTCCAATACATCGTCCAAGTTC-3' }\end{array}$ \\
\hline RhoA & NM_001313946.1 & $\begin{array}{l}\text { Forward: 5'-ATAGTGGATGAGCTGTGAGTGC-3' } \\
\text { Reverse: 5'-ACCAGACCGTGGACTAACGA-3' }\end{array}$ \\
\hline$M M P-13$ & NM_002427.3 & $\begin{array}{l}\text { Forward: 5'-AGTTCGGCCACTCCTTAGGT-3' } \\
\text { Reverse: 5'-TGGTAATGGCATCAAGGGAT-3' }\end{array}$ \\
\hline
\end{tabular}

Taq II (Takara), and $1 \mu 1$ of cDNA. GAPDH gene was used to normalize the data, and relative expression analysis was performed using $2^{-\Delta \Delta \mathrm{CT}}$ method. Products were confirmed through $2 \%$ agarose gel electrophoresis.

\section{Sub-G1 DNA content assays}

To reveal the effect of $P$. chenur on apoptosis, HCT116 cells were exposed to various concentrations of the extract $(0,140,180$, and $220 \mu \mathrm{g} / \mathrm{ml})$ for $48 \mathrm{~h}$. Briefly, $200 \mu \mathrm{l}$ of PI (10 $\mu \mathrm{l}$ of PI, $0.5 \mu \mathrm{l}$ of RNase, and $189.5 \mu \mathrm{l}$ of PBS buffer) was added to the prepared sample and incubated at $37{ }^{\circ} \mathrm{C}$ until injection to the flow cytometry instrument. Ratio of Dead (Sub-G1 phase) cells was calculated by a flow cytometry device (Partec, Germany).

\section{Annexin V/PI assay}

Annexin V-FITC/PI staining (eBioscience, USA) was performed to confirm apoptosis. At first, $4 \times 10^{6}$ cells were seeded in four flasks and incubated at $37{ }^{\circ} \mathrm{C}$. After 24 hours, the culture medium was disposed, and the cells were incubated for $48 \mathrm{~h}$ in different concentrations of $P$. chenur extract $(140,182.1$, and $220 \mu \mathrm{g} / \mathrm{ml})$. After 48 hours, the cells were collected, and $1 \mathrm{ml}$ of PBS was added to the cell precipitate and then centrifuged at $1000 \times \mathrm{g}, 4{ }^{\circ} \mathrm{C}$ for 5 minutes. The supernatant was discharged, and depending on the precipitate concentration, 300 to $350 \mu \mathrm{l}$ of reagent buffer was added to the cellular deposition and was incubated for 15 minutes. Next, Annexin V/PI staining was conducted to detect apoptotic and necrotic cells, which was as follows: $5 \mu$ l of Annexin $V$ was added to the suspension and was incubated for $30 \mathrm{~min}$ at ambient temperature. Then $5 \mu$ l of PI was augmented, followed by 15-min incubation time at ambient temperature. Finally, suspensions were injected in a flow cytometry device (Becton-Dickinson, San Diego, CA, USA) and analyzed by CellQuest software Version 5.2.

\section{Scratch test}

Scratch test is an easy and a reliable way to investigate the effect of chemical substances on the ability of cell proliferation and migration in in vitro studies. First, $75 \times 10^{3}$ cells were seeded per each well of a 24-well plate in DMEM high glucose medium. After 24 hours, when cell confluence reached 80-90\%, scratches were made in each well by a sterile $100-\mu 1$ pipette tip, and debris was removed through washing with PBS. The cells were incubated for $48 \mathrm{~h}$ in the diverse concentrations of $P$. chenur extract (140, 182.1, and $220 \mu \mathrm{g} / \mathrm{ml}$ ). Then the images were taken from four groups, at time 0 and 48 hours later, in three independent experiments, and wound closure was measured by the NIH ImageJ software in treated and control groups. In order to improve the accuracy of measurement of relative migration, the captured images were changed into binary images according to the method used by Khodadadi et al. ${ }^{[13]}$.

\section{Antioxidant assay}

Antioxidant activity of the extract was evaluated by DPPH and iron ions chelating assays ${ }^{[14]}$. Antioxidant activity of different concentrations of $P$. chenur extract was calculated as a percentage relative to the positive control. $\mathrm{IC}_{50}$ value was defined as an effective concentration of our extract needed for scavenging $50 \%$ of radical activity and chelating $50 \%$ of iron ions in DPPH and iron chelating assay, respectively $^{[15]}$. 


\section{DPPH radical scavenging}

DPPH is a chemical dark powder compound with the molecular weight of $394.32 \mathrm{~g} / \mathrm{mol}$ and is used to determine the amount of free radicals in the system. This compound is radically soluble in ethanol and has the maximum absorbance at $517 \mathrm{~nm}$. It becomes more stable by taking electrons, and its absorption decreases at $517 \mathrm{~nm}$. Briefly, $200 \mu \mathrm{l}$ of different concentrations of $P$. chenur extract and BHA were prepared in a similar way (in $95 \%$ of methanol). Methanol and BHA were used as the negative and positive controls, at the same order. Then $800 \mu$ of DPPH solution $(0.15 \mathrm{mM})$, was dissolved in $95 \%$ ethanol and was added to each sample. Finally, all samples were mixed well and were incubated in the dark at room temperature for 30 minutes. Absorbance of all solutions was measured at $517 \mathrm{~nm}$. The following equation shows how antioxidant activity of the extract was calculated ${ }^{[16]}$, where, $\mathrm{A}_{\text {control }}$ and $\mathrm{A}_{\text {sample }}$ are the amounts of control and sample absorbance at $517 \mathrm{~nm}$, respectively.

$\left(\left[\mathrm{A}_{\text {control }}-\mathrm{A}_{\text {sample }}\right] / \mathrm{A}_{\text {control }}\right) \times 100=\mathrm{DPPH}$ free radical scavenging $(\%)$

\section{Iron chelating activity}

By applying iron-chelating test, we measured the percentage of iron ions absorbed by a substance ${ }^{[15]}$. After adding iron dichloride $\left(\mathrm{FeCl}_{2}\right)$ to a solution containing $P$. chenur extract, the extract compounds began to absorb iron ions and did not allow the reaction between free iron ions and ferrozine molecules. Ferrozine, with a molecular weight of $492.46 \mathrm{~g} / \mathrm{mol}$, acts as an indicator for iron ions in the solution $^{[17]}$. At first, $200 \mu \mathrm{l}$ of different concentrations of the extract and EDTA were prepared in methanol, and $200 \mu \mathrm{l}$ of methanol without extract and EDTA were used as the controls. Then $500 \mu$ of distilled water was added to each microtube, followed by vigorous spin. Next, $100 \mu \mathrm{l}$ of $\mathrm{FeCl} 2$ was added and was incubated for 3 minutes at ambient temperature. In the final step, $200 \mu \mathrm{l}$ of $5 \mathrm{mmol}$ of Ferrozine was added and was incubated in dark at room temperature for 10 minutes. Absorbance of all solutions was measured at $562 \mathrm{~nm}$. The iron chelating effect was calculated according to the following equation, where $\mathrm{A}_{\text {control }}$ and $\mathrm{A}_{\text {sample }}$ are the amounts of control and sample absorbance at $517 \mathrm{~nm}$, respectively ${ }^{[17]}$.

Iron chelating activity $(\%)=\left[\left(1-\left(\mathrm{A}_{\text {Sample }} / \mathrm{A}_{\text {Control }}\right)\right] \times 100\right.$

\section{Statistical analysis}

Data were analyzed using GraphPad Prism 6 (Graph Pad Prism Inc., USA). Quantitative variables were presented as mean \pm standard deviation (mean $\pm \mathrm{SD}$ ). Differences between the groups were analyzed by oneway ANOVA and $t$-test. The $p<0.05$ was considered as statistically significant.

\section{RESULTS}

\section{Effect of $P$. chenur methanolic extract on cell viability}

In this study, the effect of different concentrations of extract on HCT-116 cells was investigated using MTT assay. As it is demonstrated in Figure1A, our extract reduced the percentage of viable cells compared to the control group, in a dose- and time-dependent manner with an $\mathrm{IC}_{50}$ value of approximately $182.1 \mu \mathrm{g} / \mathrm{ml}$ and $163.2 \mu \mathrm{g} / \mathrm{ml}$ after 48 and 72 hours of incubation, respectively. Also, Vero cells, as normal cells treated with different concentrations of $P$. chenur extract, showed no significant decrease in the cell viability

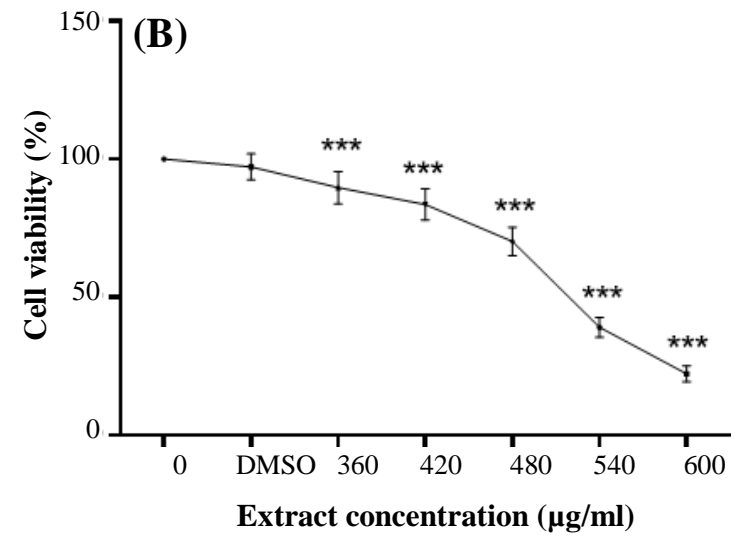

Fig. 1. Toxicity effect of $P$. chenur methanolic extract on HCT-116 and Vero cells. (a) HCT-116 cells were treated with various concentrations of extract, followed by MTT assay. The extract reduced the vitality of the cells compared to the control group. (b) Vero cells, which were treated with different concentrations of the $P$. chenur extract showed cytotoxic effects at concentrations $>\mathrm{IC}_{50}$ value for HCT-116 cells $(360 \mu \mathrm{g} / \mathrm{ml})$. Data are presented as the mean $\pm \operatorname{SD}(\mathrm{n}=8) ;{ }^{* * * *} p<0.001$. 

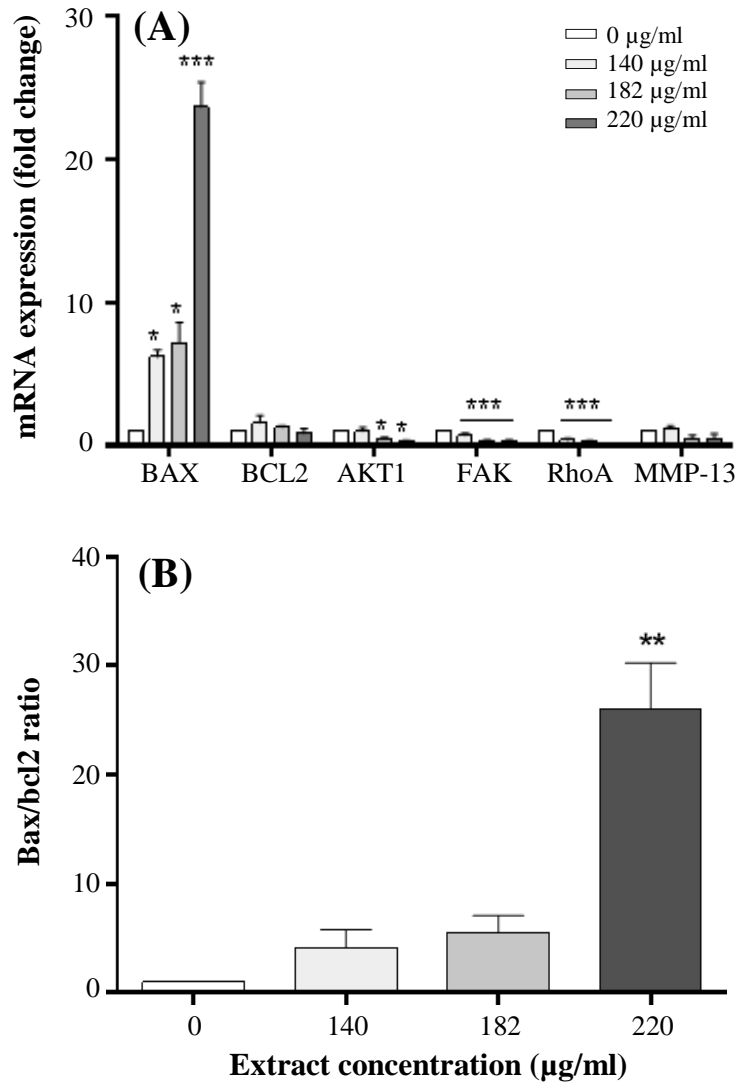

Fig. 2. Gene expression effects of $P$. chenur methanolic extract (A) Effect of the extract on expression of $B A X, B C L-2$, $A K T 1, F A K$, RhoA, and MMP-13 genes in HCT-116 cells within 48 hours. (B) Increased $B A X / B C L-2$ ratio observed in real-time PCR resulted in extract-treated cells vs. -untreated cells. Data are presented as the mean $\pm \mathrm{SD} .{ }^{*} p<0.05,{ }^{* *} p<0.01$, ${ }^{* * * *} p<0.001$ vs. the control

even up to a concentration of $360 \mu \mathrm{g} / \mathrm{ml}$ (Fig. 1B). $\mathrm{IC}_{50}$ value for Vero cells within 48 hours was equal to 517.9 $\mu \mathrm{g} / \mathrm{ml}$.

Effect of $P$. chenur methanolic extract on the expression of $B A X, B C L-2, A K T 1, F A K, R h o A$, and $M M P-13$ genes

As shown in Fig. 2A, $P$. chenur extract increased the expression of $B A X$ gene as well as decreased $F A K$, RhoA, and MMP-13 genes significantly in the treated groups compared to the control group. Also, the expression of BCL-2 decreased at the concentration of $220 \mu \mathrm{g} / \mathrm{ml}$ of our extract, but it was not significant. Similarly, a significant decrease was found in the expression of AKT1 at the concentrations of $182 \mu \mathrm{g} / \mathrm{ml}$ and $220 \mu \mathrm{g} / \mathrm{ml}$. $B A X / B C L-2$ ratio elevated significantly compared to the control group (Fig. 2B).

\section{Sub-G1 DNA content and apoptosis measurement}

In order to evaluate the effect of $P$. chenur on cell distribution in different phases of cell cycle, flow cytometric analysis was carried out in cells treated with various concentrations of $P$. chenur methanolic extract. Results demonstrated that the extract increased the percentage of cellular accumulation in the Sub-G1 phase in treated groups compared to the control group in a dose-dependent manner (Fig. 3A and 3B and Table $2)$. For the confirmation of the apoptotic effect of $P$. chenur, the cells were stained with Annexin V/PI. A significant increase was observed in the percentage of AnnexinV/PI positive cells in cells treated with $P$. chenur methanolic extract compared to the control group (Fig. 3C and 3D and Table 3).

\section{Effect of $P$. chenur methanolic extract on antioxidant activity (DPPH free radical scavenging and iron ions chelating)}

Results showed that $P$. chenur has higher ability to scavenge DPPH radicals than BHA, as a strong synthetic antioxidant. DPPH free radical scavenging at the concentrations of $182.1 \mu \mathrm{g} / \mathrm{ml}$ of methanolic extract of $P$. chenur and BHA was equal to $63.61 \%$ and $45.17 \%$, respectively. Also, $\mathrm{IC}_{50}$ values (for $\mathrm{DPPH}$ free radical scavenging) of extract and $\mathrm{BHA}$ were equal to $46.17 \mu \mathrm{g} / \mathrm{ml}$ and $251.7 \mu \mathrm{g} / \mathrm{ml}$, at the same order. Furthermore, it was found that $P$. chenur methanolic extract has iron ions chelating property. Iron ions chelating activity at the concentrations of $182.1 \mu \mathrm{g} / \mathrm{ml}$ of $P$. chenur extract and EDTA was equal to $1.39 \%$ and $53.12 \%$, respectively. $\mathrm{IC}_{50}$ values of our extract and EDTA were equal to $6.34 \mu \mathrm{g} / \mathrm{ml}$ and $130.41 \mu \mathrm{g} / \mathrm{ml}$, correspondingly. Based on the results, a direct relationship was observed between $P$. chenur methanolic extract concentration and DPPH free radical scavenging as well as iron ions chelating activity (Fig. 4).

\section{Migration assay}

Scratch test was used to measure the effect of methanolic extract of $P$. chenur on cell migration. As shown in Figure 5, the number of migrated cells and wound closure in all the treated groups decreased significantly compared to the control group so that the migration rate was inhibited perfectly at the concentration of $220 \mu \mathrm{g} / \mathrm{ml}$ of $P$. chenur.

\section{DISCUSSION}

CRC is the second leading cause of cancer-related death in the world ${ }^{[18]}$. There is no proper procedure for early detection of CRC, and common cancer treatments have many side effects ${ }^{[19]}$. Over the past 20 years, more than $50 \%$ of commonly used drugs have been derived directly from plant derivatives, or some of the plant derivatives were considered as patterns to prepare some effective drugs ${ }^{[2]}$. The effects of Peucedanum species on cancer cells can be attributed 

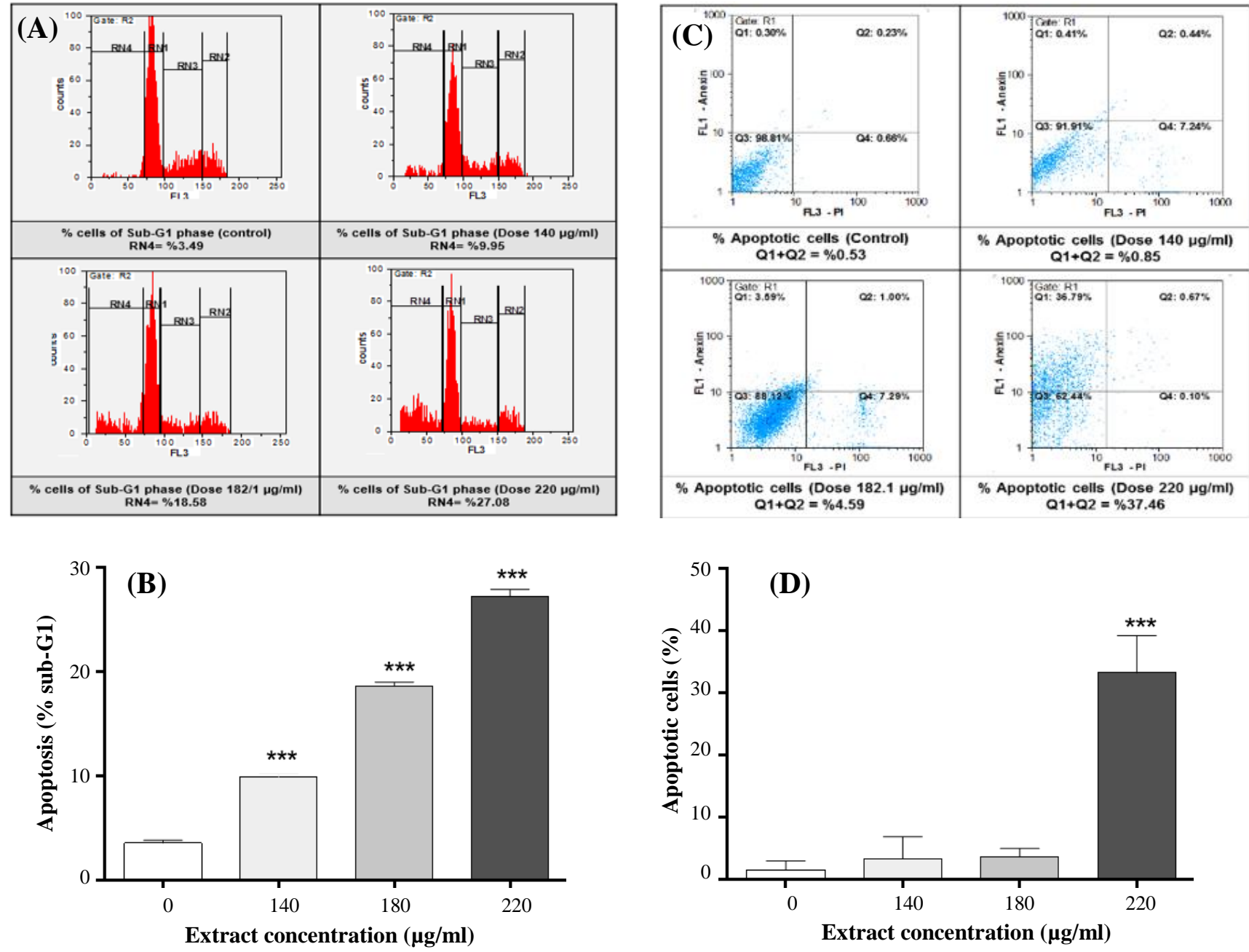

Fig. 3. Effect of $P$. chenur on cell cycle progression and apoptosis. (A) P. chenur methanolic extract effect on cell cycle alteration. (B) The fraction of Sub-G1 cells increased in the treated groups in a dose-dependent manner. (C) The effect of the extract on the induction of apoptosis in HCT-116 cells. (D) Apoptotic cells increased in treated groups in a dose-dependent manner compared to the control group. Data are presented as the mean $\pm \operatorname{SD}\left(\mathrm{n}=3 .{ }^{* * * *} p<0.001\right)$.

to chemopreventive activity ${ }^{[20]}$, anti-proliferative activity $^{[21,22]}$, induction of apoptosis ${ }^{[23]}$, growth retardation $^{[24]}$, antioxidant properties ${ }^{[14]}$, limitation of cellular invasion ${ }^{[25]}$, and synergistic effects with other anticancer drugs ${ }^{[22]}$.

For the first time, the results of our study showed anti-proliferative and suppressive ability of $P$. chenur methanolic extract on human colon cancer HCT-116 cells, while under the same condition, it did not inhibit cell proliferation of Vero cells $\left(\mathrm{IC}_{50}\right.$ value at concentration of $182.1 \mu \mathrm{g}$ vs. $517.9 \mu \mathrm{g}$, respectively). To the best of our knowledge, anticancer effects of limited species of this plant, including Peucedanum nebrodense $^{[21]}$ and Peucedanum japonicum ${ }^{[26]}$, have been investigated. For instance, the effect of $P$. japonicum extract on induced colon cancer in F344 rats has been reported ${ }^{[20]}$.

Our survey on apoptosis-related genes revealed that
$P$. chenur methanolic extract up-regulates $B A X$ gene significantly in treated groups, but it down-regulates the expression of $B C L-2$ and $A K T 1$. Besides, $B A X / B C L-2$ ratio increased. Inducible apoptosis and cell cycle alteration in HCT-116 cells by $P$. chenur were supported by flow cytometric analysis. Considering our results, it could be proposed that the apoptotic effects of $P$. chenur methanolic extract occurs through the mitochondrial pathway.

Cancer development is strongly associated with impaired apoptosis process ${ }^{[27]}$ and immortal cancer cells show a major alteration in apoptosis pathways ${ }^{[28]}$. In mitochondrial-dependent apoptosis pathway, $B A X$ (pro-apoptotic) proteins create an external channel in mitochondrial membrane, thereby entering cytochrome $\mathrm{C}$ to cytoplasm and connecting to Apaf-1 and procaspase- 9 complexes and then forming apoptosome complex $^{[9]}$. Apoptosome activates porocaspase-9 
Table 2. Results of $P$. chenur effect on cell cycle alteration

\begin{tabular}{ccccc}
\hline $\begin{array}{c}\text { Concentration } \\
(\boldsymbol{\mu g} / \mathbf{m l})\end{array}$ & $\begin{array}{c}\text { Sub-G1 } \\
(\boldsymbol{\%})\end{array}$ & $\begin{array}{c}\text { G1 } \\
(\boldsymbol{\%})\end{array}$ & $\begin{array}{c}\text { S } \\
(\boldsymbol{\%})\end{array}$ & $\begin{array}{c}\text { G2/M } \\
(\boldsymbol{\%})\end{array}$ \\
\hline control & $3.49 \pm 0.05$ & $60.71 \pm 0.06$ & $20.21 \pm 0.03$ & $13.78 \pm 0.04$ \\
140 & $9.95 \pm 0.01$ & $54.01 \pm 0.05$ & $19.50 \pm 0.03$ & $16.11 \pm 0.02$ \\
182.1 & $18.58 \pm 0.2$ & $55.33 \pm 0.5$ & $15.00 \pm 0.3$ & $12.13 \pm 0.2$ \\
220 & $27.08 \pm 0.6$ & $47.25 \pm 0.9$ & $11.63 \pm 0.2$ & $13.26 \pm 0.3$ \\
\hline
\end{tabular}

Data are presented as the mean $\pm \operatorname{SD}(n=3)$.

proteolysis, and activated caspase- 9 is released, which activates executive Caspase cascades such as Caspase$3^{[29]}$. In the absence of apoptosis stimulator, $B C L-2$ is activated and prevents all of these events and causes cell survival $^{[30]}$. Also, phosphorylation of Caspase-9 is induced by active $A K T 1$ protein which, in turn, decreases the activity of Caspase-9 and inhibits cellular apoptosis ${ }^{[31]}$. Moreover, decline of $B A X / B C L-2$ ratio results in resistance to apoptosis ${ }^{[32]}$, and reduced expression ratio of $B A X / B C L-2$ genes in colon cancer causes apoptosis resistance $^{[32]}$.

Our reasults were confirmed by the study conducted by Fong et al. $^{[23]}$ who reported that pyranocoumarin purified from Peucedanum praeruptorum extract increases $B a x$ and $B A X / B C L-2$ ratio in HL-60 leukemia cells. They also indicated that the mentioned extract causes apoptotic DNA, nucleolar fragnmentation, and induction of apoptosis in multidrug-resistant cancer cell lines ${ }^{[23,33]}$.

Migration is a complex process that plays an important role in the invasion and metastasis of cancer cells $^{[4]}$. Active $A K T 1$ increases invasion intensively ${ }^{[4]}$. $F A K$, as a tyrosine kinase, is associated with signaling between cells and extracellular matrix and acts as a scaffold protein in cellular connections in metastatic colon cancer and overexpresses in metastatic colon cancer $^{[34]}$. RhoA is a small Ras-family GTPase that contributes to the organization of cellular skeletons, invasion, transcription, and cell proliferation. It also controls the formation of focal cell adhesion and stressbearing strands in the cell ${ }^{[35]}$. Overexpression of $R h o A$ has been proved in colon cancer ${ }^{[36]}$.

$M M P s$ are proteolytic enzymes that break down the extracellular matrix and cause cellular migration and metastasis. Expression of $M M P-13$, as a member of collagenases in the cancerous tissue, is significantly higher than healthy tissue ${ }^{[37]}$. FAK, by activating RhoA, regulates the structure of cellular skeleton and cell-cell communication ${ }^{[38]}$ and adjusts the contraction force of migration by regulating RhoA and MMPs in separate pathways ${ }^{[39]}$. MMP-13 has a very important function in tumor invasion and metastasis in most malignancies by degrading type II collagen. Compared to breast or lung cancer cell lines, MMP13 is highly expressed in CRC cell lines. MMP13 mRNA upregulation is correlated with tumor size, tumor invasiveness, and lymph node metastasis ${ }^{[40,41]}$.

In the present study, $P$. chenur methanolic extract reduced the expression of $A K T 1, F A K$, RhoA, and $M M P-13$ genes in HCT-116 cells. Furthermore, a significant decrease in cell migration was confirmed by the scratch test in HCT-116 cells treated with the methanolic extract of $P$. chenur, even migration was inhibited completely in $\mathrm{IC}_{50}$ value at the concentration of $220 \mu \mathrm{g}$. In agreement with our research, $P$. japonicum ethanol extract has been found to inhibit invasion by decreasing $M M P-9$ expression and inhibits $P K C / N f-K B$ signaling pathway in MCF-7 breast cancer cells $^{[25]}$. These results suggest the inhibitory effect of our extract on motility and migration of tumoral cells through FAK/Rho-A/MMP-13 signaling pathways; thus, it can be proposed as a new chemopreventive agent to prevent metastasis.

Oxidation is a vital process in living cells. Free radicals are one of the oxidation products and are highly reactive and harmful molecules influencing the vital macromolecules and aggravate progression of the cancer $^{[42]}$. Antioxidant substances can protect the cell from oxidative damage through neutralizing the activity of free radicals ${ }^{43]}$. Antioxidant effect of several genus of Peucedanum has been confirmed ${ }^{[14]}$.

Table 3. Results of AnnexinV/PI assay

\begin{tabular}{ccccc}
\hline $\begin{array}{c}\text { Concentration } \\
(\boldsymbol{\mu g} / \mathbf{m l})\end{array}$ & $\begin{array}{c}\text { Necrotic cells } \\
(\boldsymbol{\%})\end{array}$ & $\begin{array}{c}\text { Late apoptotic } \\
\text { cells }(\boldsymbol{\%})\end{array}$ & $\begin{array}{c}\text { Early apoptotic } \\
\text { cells }(\boldsymbol{\%})\end{array}$ & $\begin{array}{c}\text { Viable } \\
\text { cells }(\%)\end{array}$ \\
\hline control & $7.98 \pm 2.0$ & $1.4 \pm 1.3$ & $0.13 \pm 0.1$ & $90.49 \pm 1.1$ \\
140 & $7.73 \pm 0.7$ & $1.57 \pm 1.6$ & $1.77 \pm 1.9$ & $88.93 \pm 4.2$ \\
182.1 & $7.81 \pm 0.7$ & $1.44 \pm 0.6$ & $2.18 \pm 1.98$ & $88.57 \pm 0.6$ \\
220 & $1.17 \pm 1.5$ & $1.89 \pm 1.7$ & $31.33 \pm 7.7$ & $65.61 \pm 4.5$ \\
\hline
\end{tabular}

Data are presented as the mean $\pm \mathrm{SD}(\mathrm{n}=3)$. 


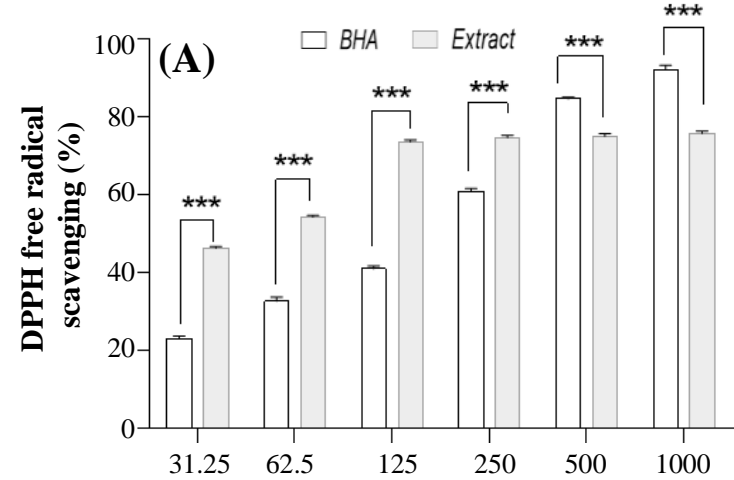

Extract and BHA concentrations $(\mu \mathrm{g} / \mathrm{ml})$

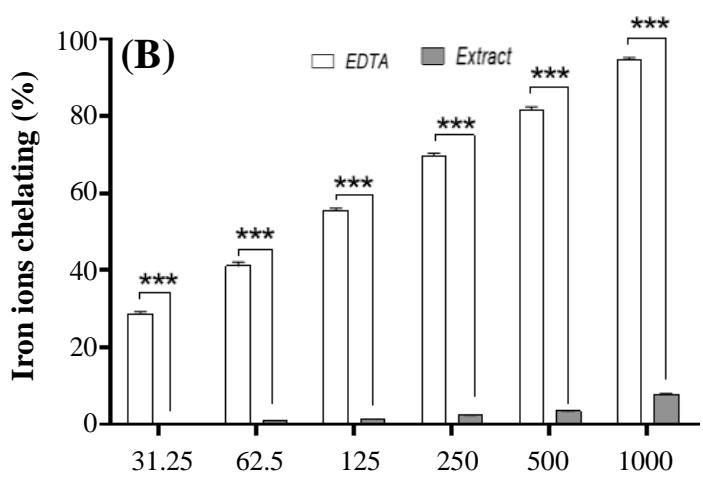

Extract and BHA concentrations $(\mu \mathrm{g} / \mathrm{ml})$

Fig. 4. The antioxidant effect of $P$. chenur methanolic extract. (A) DPPH free radicals scavenging at various concentrations of extract compared to the similar concentration of standard antioxidant (BHA). (B) Percentage of iron ions chelating at different concentrations of $P$. chenur extract compared to the same concentrations of EDTA. Results are presented as the mean \pm SD $(n=3)$. ${ }^{* * *} p<0.001$.

The methanolic extract of Peucedanum graveolens has a high thermal and $\mathrm{pH}$ stability, and its antioxidant effect increases at high temperatures and $\mathrm{pH}$ levels ${ }^{[44]}$. In this study, two antioxidant tests, DPPH and iron chelating, were used ${ }^{[14]}$. Results clearly indicated a direct association between antioxidant activity and $P$. chenur methanolic extract concentration. In DPPH antioxidant test, higher antioxidant activity of our extract was shown compared to standard antioxidants, BHA ( $63.61 \%$ vs. $45.17 \%$ ), as well as lower $\mathrm{IC}_{50}$ value to scavenging free radicals $(46.17 \mu \mathrm{g} v \mathrm{vs} .251 .7 \mu \mathrm{g})$.

Although iron chelating test showed that our extract has lower ability to chelate iron ions compared to EDTA as a standard compound, $\mathrm{IC}_{50}$ value for the methanolic extract of $P$. chenur and EDTA were estimated to be about $6.34 \mu \mathrm{g}$ and $130.41 \mu \mathrm{g}$, respectively. Tepe et $a l .{ }^{[45]}$ suggested that essential oils obtained from Peucedanum longifolium and
Peucedanum palimbioides extracts have $8.59 \%$ and $10.67 \%$ free radical scavenging activity of DPPH at 0.2 mg of concentration and have $12.42 \%$ and $90.39 \%$ Iron ions chelating activity at $2 \mathrm{mg}$ of concentration, respectively. Meanwhile, DPPH free radicals scavenging $\mathrm{IC}_{50}$ for polyphenols and flavonoids derived from Peucedanum Pastinacifolium hydroalcoholic extract has been indicated to be equal to $469.4 \mu \mathrm{g}$, and this value for iron chelating was equal to $657.5 \mu \mathrm{g}^{[14]}$. As a result, $P$. chenur methanolic extract has higher antioxidant ability compared to other Peucedanum species at lower concentration; thus, $P$. chenur methanolic extract may be introduced as a new antioxidant agent in the field of medicine in the future.

Altogether, our study, for the first time, showed the notable anti-proliferative effect of $P$. chenur methanolic extract in the induction of apoptosis through mitochondrial pathway as was evident from
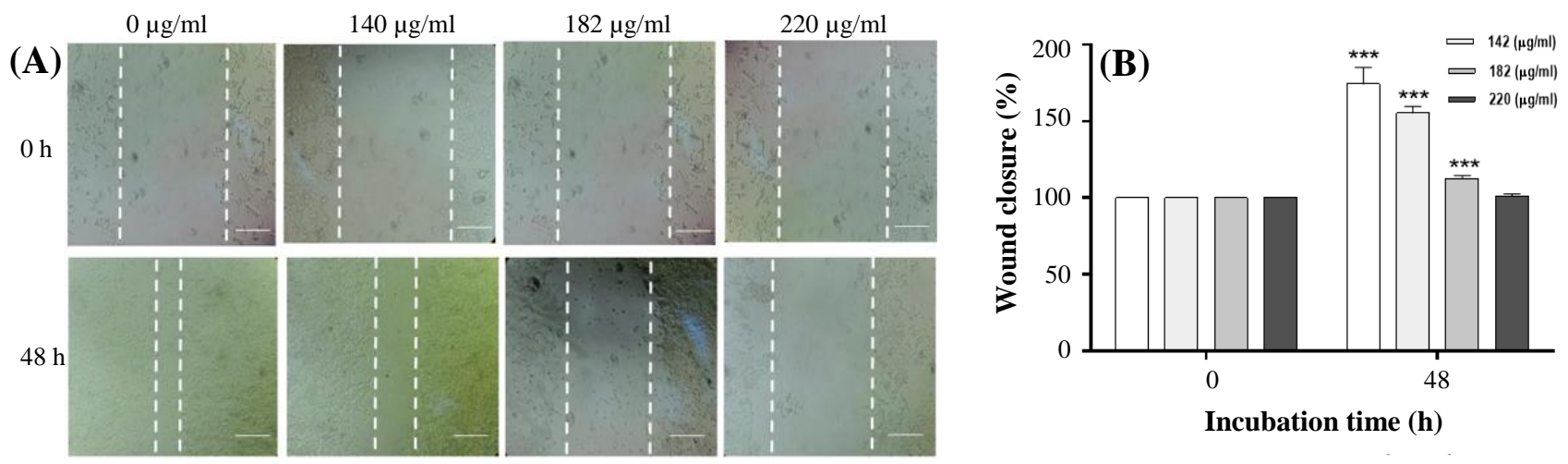

Fig. 5. P. chenur methanolic extract suppressed cell migration. (A) Representative image of the extract effect on migration of HCT116 cells treated with different concentrations of $P$. chenur at time zero and 48 hours later. Migration rate of the cells reduced in the treated groups compared to the control group in a dose-dependent manner. (B) Wound closure was quantified randomly in three fields in all groups. Data are presented as the mean $\pm \operatorname{SD}(n=3) .{ }^{* * *} p<0.001$ vs. control. 
the increased $B A X / B C L-2$ ratio and the inhibition of invasion through the reduction of $A K t 1, F A K, R h o A$, and $M M P-13$ expression. It also may be proposed as a strong anti-oxidative agent in the future studies, due to its ability to remove free radicals. Collectively, this natural agent may be turn out as a novel therapeutic strategy in colon cancer treatment.

\section{ACKNOWLEDGMENTS}

Authors thank H. Tanzadepanah for valuable assistance in some experiments. The authors also gratefully acknowledge the Vice Chancellor for Research and Technology, Hamadan University of Medical Sciences for their support of this study (Grant no. 9603231871$)$.

\section{CONFLICT OF INTEREST. None declared.}

\section{REFERENCES}

1. Ather HM, Sarfraz M, Anwaar T. Colorectal cancer (CRC); Obesity and its co-relation with staging. The professional medical journal 2016; 23(4): 364-369.

2. Asadi-Samani M, Kooti W, Aslani E, Shirzad H. A systematic review of Iran's medicinal plants with anticancer effects. Journal of evidence-based complementary and alternative medicine 2016; 21(2): 143-153.

3. Hanahan D, Weinberg RA. Hallmarks of cancer: the next generation. Cell 2011; 144(5): 646-674.

4. Turečková J, Vojtěchová M, Krausová M, Šloncová E, Korínek V. Focal adhesion kinase functions as an akt downstream target in migration of colorectal cancer cells. Translational oncology 2009; 2(4): 281-290.

5. Gutman M, Fidler IJ. Biology of human colon cancer metastasis. World journal of surgery 1995; 19(2): 226234.

6. Glade MJ. Food, nutrition, and the prevention of cancer: a global perspective. American Institute for Cancer Research/World Cancer Research Ffund, American Institute for Cancer Research, 1997. Nutrition 1999; 15(6): 523-526.

7. Millimouno FM, Dong J, Yang L, Li J, Li X. Targeting apoptosis pathways in cancer and perspectives with natural compounds from mother nature. Cancer prevention research (Philadelphia) 2014; 7(11): 10811087.

8. Sun SY, Hail Jr N, Lotan R. Apoptosis as a novel target for cancer chemoprevention. Journal of the national cancer institute 2004; 96(9): 662-672.

9. Nuñez G, Benedict MA, Hu Y, Inohara N. Caspases: the proteases of the apoptotic pathway. Oncogene 1998; 17(25): 3237-3245.

10. Sarkhail P. Traditional uses, phytochemistry and pharmacological properties of the genus Peucedanum: A review. Journal of ethnopharmacology 2014; 156: 235270.

11. Moradi M, Solgi R, Najafi R, Tanzadehpanah $H$, Saidijam M. Determining optimal cell density and culture medium volume simultaneously in MTT Cell proliferation assay for adherent cancer cell lines. HELIX 2018; 8(2): 3274-3280.

12. Moradi M, Najafi R, Amini R, Solgi R, Tanzadehpanah H, Esfahani AM, Saidijam M. Remarkable apoptotic pathway of hemiscorpius lepturus scorpion venom on CT26 cell line. Cell biology and toxicology 2019; 35(4): 373-385.

13. Khodadadi I, Ardebili SMS, Eyvazzadeh O, Zargari K, Moradi M. Comparing the sensitivity of spot test method and a novel computer vision system for iron detecting in fortificated flours. Food analytical methods 2014; 7(6): 1213-1218.

14. Movahedian A, Zolfaghari B, Mirshekari M. Antioxidant effects of hydroalcoholic and polyphenolic extracts of Peucedanum pastinacifolium Boiss. \& Hausskn. Research in pharmaceutical sciences 2016; 11(5): 405-411.

15. Tanzadehpanah H, Asoodeh A, Saidijam M, Chamani J, Mahaki H. Improving efficiency of an angiotensin converting enzyme inhibitory peptide as multifunctional peptides. Journal of biomolecular structure and dynamics 2017; 36(14): 3803-3818.

16. Shimada K, Fujikawa K, Yahara K, Nakamura $T$. Antioxidative properties of xanthan on the autoxidation of soybean oil in cyclodextrin emulsion. Journal of agricultural and food chemistry 1992; 40(6): 945-948.

17. Decker EA, Welch B. Role of ferritin as a lipid oxidation catalyst in muscle food. Journal of agricultural and food chemistry 1990; 38(3): 674-677.

18. Simon K. Colorectal cancer development and advances in screening. Clinical interventions in aging 2016; 11: 967-976.

19. A Amin A, Gali-Muhtasib H, Ocker M, Schneider-Stock R. Overview of major classes of plant-derived anticancer drugs. International journal biomedical science 2009 ; 5(1): 1-11.

20. Morioka T, Suzui M, Nabandith V, Inamine M, Aniya Y, Nakayama T, Ichiba T, Mori H, Yoshimi N. The modifying effect of peucedanum japonicum, a herb in the Ryukyu Islands, on azoxymethane-induced colon preneoplastic lesions in male F344 rats. Cancer letters 2004; 205(2): 133-141.

21. Schillaci D, Venturella F, Venuti F, Plescia F. Antimicrobial and antiproliferative activity of peucedanum nebrodense (Guss.) strohl. Journal of ethnopharmacology 2003; 87(1): 99-101.

22. Liang T, Yue W, Li Q. Chemopreventive effects of Peucedanum praeruptorum dunn and its major constituents on SGC7901 gastric cancer cells. Molecules 2010; 15(11): 8060-8071.

23. Fong WF, Zhang JX, Wu JY, Tse KW, Wang C, Cheung HY, Yang MS. Pyranocoumarin $\left({ }^{+-}\right)-4$ '-O-acetyl-3'-Oangeloyl-cis-khellactone induces mitochondrialdependent apoptosis in HL-60 cells. Planta medica 2004; 70(6): 489-495.

24. Li XM, Jiang XJ, Yang K, Wang LX, Wen SZ, Wang F. 
Prenylated coumarins from heracleum stenopterum, Peucedanum praeruptorum, Clausena lansium, and Murraya paniculata. Natural products and bioprospecting 2016; 6(5): 233-237.

25. Kim JM, Noh EM, Kim HR, Kim MS, Song HK, Lee M, Yang SH, Lee GS, Moon HC, Kwon KB. Suppression of TPA-induced cancer cell invasion by Peucedanum japonicum thunb. extract through the inhibition of $\mathrm{PKC} \alpha / \mathrm{NF}-\kappa \mathrm{B}-$ dependent MMP-9 expression in MCF-7 cells. International journal of molecular medicine 2016; 37(1): 108-114.

26. Jang KC, Kim SC, Song EY, Um YC, Kim SC, Lee YJ. Isolation and identification of anticancer and antiinflammatory substances in Peucedanum japonicum thunb. Acta horticulturae 2008; 765: 49-54.

27. Krysko DV, Vanden Berghe T, D'Herde K, Vandenabeele P. Apoptosis and necrosis: detection, discrimination and phagocytosis. Methods 2008; 44(3): 205-221

28. Plati J, Bucur O, Khosravi-Far R. Apoptotic cell signaling in cancer progression and therapy. Integrative biology (Camb) 2011; 3(4): 279-296.

29. Salvesen GS. Caspases and apoptosis. Essays in biochemistry 2002; 38: 9-19.

30. Mirza A, McGuirk M, Hockenberry TN, Wu Q, Ashar H, Black S, Wen SF, Wang L, Kirschmeier P, Bishop WR. Human survivin is negatively regulated by wildtype p53 and participates in p53-dependent apoptotic pathway. Oncogene 2002; 21(17): 2613-2622.

31. Downward J. PI 3-kinase, Akt and cell survival. Proceedings of the seminars in cell and developmental biology 2004; 15(2): 177-182.

32. Khodapasand E, Jafarzadeh N, Farrokhi F, Kamalidehghan B, Houshmand M. Is Bax/Bcl-2 ratio considered as a prognostic marker with age and tumor location in colorectal cancer? Iranian biomedical journal 2015; 19(2): 69-75.

33. Wu JYC, Fong WF, Zhang JX, Leung CH, Kwong HL, Yang MS, Li D, Cheung HY. Reversal of multidrug resistance in cancer cells by pyranocoumarins isolated from radix peucedani. European journal of pharmacology 2003; 473(1): 9-17.

34. Cance WG, Harris JE, Iacocca MV, Roche E, Yang X, Chang J, Simkins S, Xu L. Immunohistochemical analyses of focal adhesion kinase expression in benign and malignant human breast and colon tissues: correlation with preinvasive and invasive phenotypes. Clinical cancer research 2000; 6(6): 2417-2423.

35. Parri M, Chiarugi P. Rac and Rho GTPases in cancer cell motility control. Cell communication and signaling 2010; 8: 23.

36. Fritz G, Just I, Kaina B. Rho GTPases are overexpressed in human tumors. International journal of cancer $1999 ;$ 81(5): 682-687.

37. Yang B, Gao J, Rao Z, Shen Q. Clinicopathological significance and prognostic value of MMP-13 expression in colorectal cancer. Scandinavian journal of clinical and laboratory investigation 2012; 72(6): 501505.

38. Badgwell DB, Lu Z, Le K, Gao F, Yang M, Suh GK, Bao JJ, Das P, Andreeff M, Chen W. The tumorsuppressor gene ARHI (DIRAS3) suppresses ovarian cancer cell migration through inhibition of the Stat 3 and FAK/Rho signaling pathways. Oncogene 2012; 31(1): 68-79.

39. Meng X, Jin Y, Yu Y, Bai J, Liu G, Zhu J, Zhao Y, Wang Z, Chen F, Lee K. Characterisation of fibronectin-mediated FAK signalling pathways in lung cancer cell migration and invasion. British journal of cancer 2009; 101(2): 327-334.

40. Huang MY, Chang HJ, Chung FY, Yang MJ, Yang YH, Wang JY, Lin SR. MMP13 is a potential prognostic marker for colorectal cancer. Oncology reports 2010; 24(5): 1241-1247.

41. Kudo Y, Iizuka S, Yoshida M, Tsunematsu T, Kondo T, Subarnbhesaj A, Deraz EM, Siriwardena SB, Tahara H, Ishimaru N, Ogawa I, Takata T. Matrix metalloproteinase-13 (MMP-13) directly and indirectly promotes tumor angiogenesis. The journal of biological chemistry 2012; 287(46): 38716-38728.

42. Zhang Y, Marcillat O, Giulivi C, Ernster L, Davies K. The oxidative inactivation of mitochondrial electron transport chain components and ATPase. Journal of biological chemistry 1990; 265(27): 16330-16336.

43. Sen S, Chakraborty R, Sridhar C, Reddy Y, De B. Free radicals, antioxidants, diseases and phytomedicines: current status and future prospect. International journal of pharmaceutical sciences review and research 2010; 3(1): 91-100.

44. Roy LG, Urooj A. Antioxidant potency, $\mathrm{pH}$ and heat stability of selected plant extracts. Journal of food biochemistry 2013; 37(3): 336-342.

45. Tepe B, Akpulat HA, Sökmen M. Evaluation of the chemical composition and antioxidant activity of the essential oils of Peucedanum longifolium (Waldst. \& Kit.) and P. palimbioides (Boiss.). Records of natural products 2011; 5: 108-116. 